\title{
IN HALTSVERZEICHNIS
}

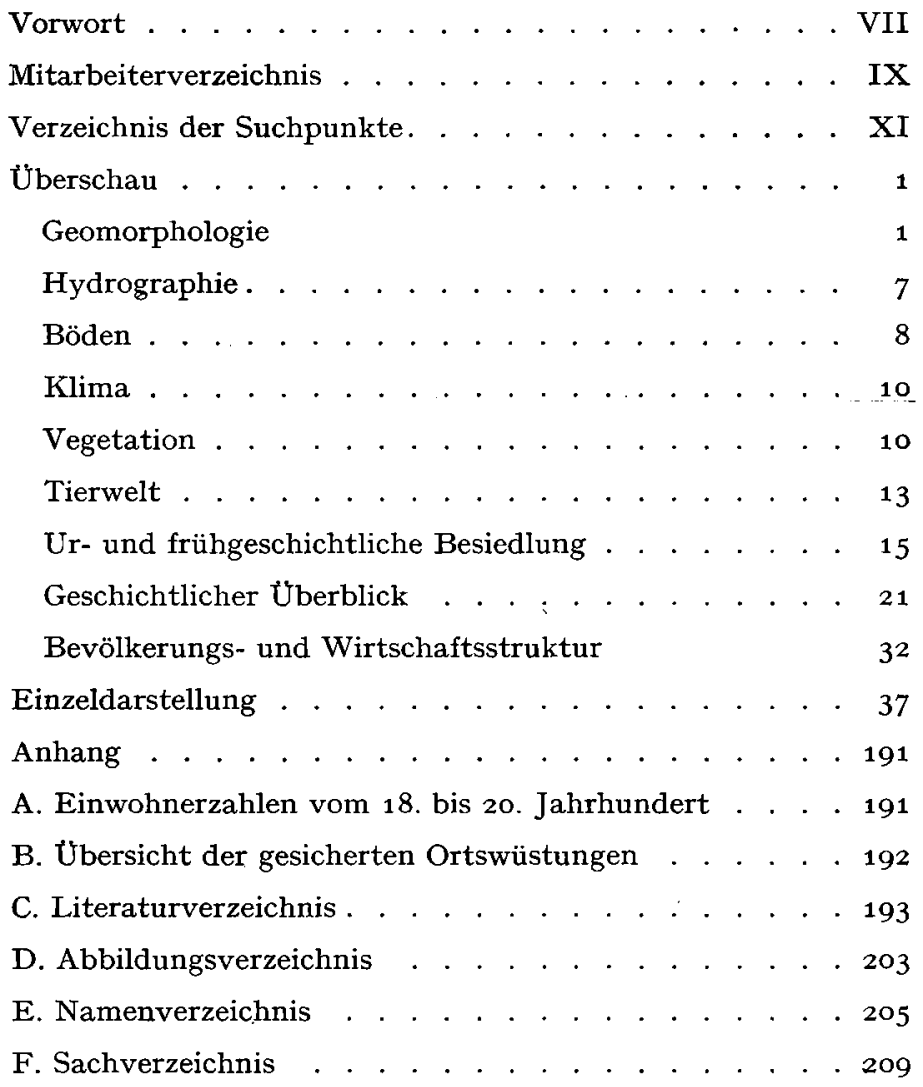


